\title{
Transfusi Rasional pada Anak
}

Pustika Amalia Wahidiyat, Nitish Basant Adnani

Departemen Ilmu Kesehatan Anak Fakultas Kedokteran Universitas Indonesia/RSUPN Dr. Cipto Mangunkusumo

\begin{abstract}
Abstrak
Transfusi darah adalah rangkaian proses memindahkan darah atau komponen darah dari donor kepada resipien. Pada kasus-kasus tertentu, transfusi darah dapat sangat bermanfaat atau bahkan menyelamatkan nyawa pasien. Transfusi darah pada praktik klinik dapat menggunakan berbagai jenis komponen, baik darah lengkap (whole blood), sel darah merah pekat (packed red cells/PRC), sel darah merah yang dicuci (washed erythrocytes/WE), trombosit, plasma segar beku (fresh frozen plasma/FFP), kriopresipitat, dan sebagainya sesuai indikasi. Untuk memastikan bahwa transfusi darah dapat memberikan manfaat yang optimal bagi resipien, penyimpanan, penanganan, dan uji kompatibilitas untuk produk darah harus dilaksanakan dengan baik sesuai pedoman. Tujuan transfusi darah secara umum untuk mengembalikan serta mempertahankan volume normal peredaran darah, mengganti kekurangan komponen selular darah, meningkatkan oksigenasi jaringan, serta memperbaiki fungsi homeostasis pada tubuh. Sari Pediatri 2016;18(4):325-31
\end{abstract}

Kata kunci: transfusi darah, homeostatis, donor

\section{Rational Blood Transfusion in Children}

Pustika Amalia Wahidiyat, Nitish Basant Adnani

\begin{abstract}
Blood transfusion refers to a process of transfer of blood or blood components from a donor to a recipient. In certain cases, blood transfusion may be highly beneficial or even save the life of a patient. The implementation of blood transfusion in clinical practice may involve different types of blood components, including whole blood, packed red cells (PRC), washed erythrocytes (WE), thrombocytes, fresh frozen plasma (FFP), cryoprecipitates, and so on, depending on the indication for transfusion. To ensure that blood transfusion leads to maximum benefits for the patient, the storage, handling, and compatibility testing for blood products should be conducted in accordance to the established guidelines. The purpose of blood transfusion in general is to maintain the normal volume of blood flow, replace the lack of a particular cellular component in the blood, improve tissue oxygenation, and maintain homeostasis of the body. Sari Pediatri 2016;18(4):325-31
\end{abstract}

Keyword: blood transfusion, homeostasis, donor.

Alamat korespondensi: Dr. dr. Pustika Amalia Wahidiyat, Sp.A(K). Pusat Thalassemia RSCM Kiara, Jl. Diponegoro No. 71, Jakarta Pusat 10430. E-mail: pa.wahidiyat@gmail.com 
$\mathrm{D}$ alam perkembangan pelayanan darah di Indonesia saat ini, pengadaan darah yang berkualitas, mudah didapat, cepat, serta dalam jumlah yang memadai harus terus ditingkatkan. Pelayanan darah merupakan salah satu mata rantai dari berbagai pelayanan medis di fasilitas kesehatan, dan memiliki peran yang penting terutama dalam tindak lanjut pada keadaan gawat darurat, persiapan tindakan operasi, dan peningkatan status kesehatan pasien pada berbagai kasus kelainan darah. ${ }^{1}$

Angka kejadian anemia berat pada anak sangat bervariasi di berbagai belahan dunia. Pada daerah dengan prevalensi anemia tinggi untuk defisiensi nutrisi, malaria, infeksi parasit, dan hemoglobinopati, anak memiliki risiko tinggi untuk terjadinya anemia berat, sehingga frekuensi pemberian transfusi darah pada anak juga akan lebih tinggi pada negara-negara tersebut. $^{2}$

Pemberian transfusi produk darah secara umum lebih jarang pada neonatus dan anak dibandingkan dengan dewasa. Populasi pasien anak yang umumnya mendapatkan transfusi adalah anak yang dirawat di ruang rawat intensif, yang akan menjalani prosedur pembedahan jantung, dengan penyakit herediter yang membutuhkan transfusi rutin seperti thalassemia mayor, dan yang sedang menjalani kemoterapi intensif untuk keganasan darah atau kanker organ tertentu. ${ }^{3}$ Pada praktik klinik, pelayanan transfusi pada neonatus dan anak memiliki banyak kesamaan dengan pelayanan transfusi pada dewasa. Namun, terdapat beberapa perbedaan penting serta keadaan khusus yang perlu diperhatikan. ${ }^{4}$ Potensi risiko dan manfaat dalam melakukan tindakan transfusi harus selalu dipertimbangkan dalam membuat keputusan untuk melakukan transfusi pada anak, dan dapat disesuaikan dengan penelitian serta pedoman transfusi yang sudah tersedia. ${ }^{3}$

\section{Pelayanan pra-transfusi}

Sebelum pemberian transfusi darah, seluruh produk darah dari donor harus dilakukan uji saring untuk mendeteksi adanya infeksi menular lewat transfusi darah (IMLTD), yang mencakup human immunodeficency virus (HIV), hepatitis $\mathrm{B}$, hepatitis $\mathrm{C}$, dan sifilis. Pemeriksaan terhadap penyakit tersebut dilakukan dengan metode nucleic acid test (NAT). Selain itu, pemeriksaan golongan darah $\mathrm{ABO}$ dan rhesus serta uji kompatibilitas harus juga dilakukan. Fasilitas yang menyediakan layanan transfusi darah harus mematuhi tata cara penyimpanan, pemantauan suhu, dan transportasi komponen darah, untuk menjamin pelayanan transfusi darah yang aman dan berkualitas. ${ }^{1}$

\section{Transfusi darah atau komponen darah pada anak}

\section{Darah lengkap/whole blood (WB)}

Pemberian transfusi WB pada umumnya dilakukan sebagai pengganti sel darah merah pada keadaan perdarahan akut atau masif yang disertai dengan hipovolemia, atau pada pelaksanaan transfusi tukar. $\mathrm{Di}$ dalam WB, masih terdapat seluruh komponen darah manusia, termasuk faktor pembekuan, sehingga dapat digunakan pada kasus perdarahan masif. ${ }^{1}$

\section{Transfusi sel darah merah pekat/packed red cells (PRC)}

Secara umum, transfusi PRC hampir selalu diindikasikan pada kadar $\mathrm{Hb}<7,0 \mathrm{~g} / \mathrm{dL}$, terutama pada keadaan anemia akut. Transfusi juga dapat dilakukan pada kadar Hb 7,0-10,0 g/dL, apaapabila ditemukan hipoksia atau hipoksemia yang bermakna secara klinis dan laboratorium. Transfusi jarang dilakukan pada kadar $\mathrm{Hb}>10,0 \mathrm{~g} / \mathrm{dL}$ kecuali terdapat indikasi tertentu, seperti penyakit yang membutuhkan kapasitas transpor oksigen lebih tinggi. Sebagai contoh, pada anak dengan anemia defisiensi besi, transfusi pada umumnya tidak dilakukan jika tidak terdapat keluhan dan anak dalam kondisi klinis baik. Sebaliknya, pada pasien anak yang membutuhkan transfusi rutin, transfusi diberikan pada kadar Hb pra-tansfusi 9,0-10,0 g/dL, untuk mempertahankan tumbuh kembang mendekati tumbuh kembang pada anak normal. ${ }^{1}$

Pada bayi prematur, transfusi PRC diindikasikan apaapabila kadar $\mathrm{Hb}<7,0 \mathrm{~g} / \mathrm{dL}$. Pada keadaan infant respiratory distress syndrome (IRDS), transfusi diberikan pada kadar $\mathrm{Hb}<12,0 \mathrm{~g} / \mathrm{dL}$ untuk bayi yang membutuhkan oksigen, atau $<10.0 \mathrm{~g} / \mathrm{dL}$ untuk bayi yang tidak membutuhkan oksigen. Pada bayi prematur dengan tanda dan gejala anemia ringan seperti takikardia atau peningkatan berat badan yang tidak adekuat, transfusi diberikan apaapabila kadar $\mathrm{Hb}$ $<10,0 \mathrm{~g} / \mathrm{dL}$. Namun, apabila terjadi tanda dan gejala 
Pustika Amalia Wahidiyat dkk: Transfusi rasional pada anak

Tabel 1. Pengertian jumlah leukosit per unit kantong darah untuk setiap komponen darah

\begin{tabular}{lc}
\hline Komponen darah & Jumlah leukosit (per unit kantong darah) \\
\hline Whole blood (WB) & $10^{9}$ \\
Packed red cells (PRC) & $10^{8}-10^{9}$ \\
Washed erythrocytes (WE) & $10^{7}$ \\
PRC leukoreduksi & $<10^{8}$ \\
PRC leukodeplesi & $<10^{6}$ \\
Trombosit konsentrat & $10^{7}-10^{8}$ \\
Trombosit apheresis & $10^{6}-10^{8}$ \\
Fresh frozen plasma (FFP) & $<10^{4}$ \\
\hline
\end{tabular}

Dikutip dari: Wahidiyat PA, Rahmartani LD, Putriasih SA. Pemakaian klinis produk darah pada kasus transfusi berulang; $2016 .^{9}$

anemia berat seperti apnea, hipotensi, atau asidosis, transfusi PRC dapat diberikan pada kadar $\mathrm{Hb}<12,0$ g/dL. ${ }^{5,6}$

Pada bayi aterm di bawah usia 4 bulan, transfusi diberikan apabila terdapat manifestasi klinis anemia seperti apnea, takikardia, atau peningkatan berat badan yang tidak adekuat apabila kadar $\mathrm{Hb}<7,0 \mathrm{~g} / \mathrm{dL}$. Transfusi PRC juga dapat diberikan pada bayi dengan anemia perioperatif yang memiliki kadar $\mathrm{Hb}<10.0 \mathrm{~g} /$ $\mathrm{dL}$, atau pada kondisi perdarahan akut yang melebihi $10 \%$ dari volume darah total yang tidak menunjukkan respon terhadap terapi lain. Transfusi PRC juga dapat diberikan pada pasien pasca operasi dengan tanda dan gejala anemia dan kadar $\mathrm{Hb}<10,0 \mathrm{~g} / \mathrm{dL}$, serta pasien yang menderita penyakit kardiopulmonal berat dengan kadar $\mathrm{Hb}<12,0 \mathrm{~g} / \mathrm{dL} .^{5-7}$

Dosis yang digunakan untuk transfusi PRC pada anak adalah $10-15 \mathrm{~mL} / \mathrm{kgBB} /$ hari apabila $\mathrm{Hb}>6,0$ $\mathrm{g} / \mathrm{dL}$, sedangkan pada $\mathrm{Hb}<5,0 \mathrm{~g} / \mathrm{dL}$, transfusi PRC dapat dilakukan dengan dosis $5 \mathrm{~mL} / \mathrm{kgBB}$ dalam 1 jam pertama. Pada keadaan darurat sisa darah yang masih ada pada kantong dihabiskan dalam 2-3 jam selanjutnya, asalkan total darah yang diberikan tidak melebihi 10-15 $\mu \mathrm{L} / \mathrm{kgBB} /$ hari. Namun, apabila jumlah transfusi yang dibutuhkan hanya sedikit, dianjurkan untuk menggunakan kantong kecil/ pediatrik. Dosis transfusi PRC pada neonatus $20 \mathrm{~mL} /$ $\mathrm{kgBB}$, dan disarankan untuk menggunakan kantong pediatrik dengan kapasitas $\pm 50 \mu \mathrm{L} /$ kantong. Pada anak, pemberian PRC $4 \mathrm{~mL} / \mathrm{kgBB}$ dapat meningkatkan kadar $\mathrm{Hb}$ sekitar $1 \mathrm{~g} / \mathrm{dL}$. Rumus untuk menghitung kebutuhan PRC adalah $[\mathrm{DHb}$ (target $\mathrm{Hb}-\mathrm{Hb}$ saat ini) $\mathrm{x}$ berat badan $\mathrm{x}$ 4], sementara kebutuhan per hari adalah $10-15 \mathrm{~kg} / \mathrm{BB} /$ hari. $^{1}$

\section{Sel darah merah miskin leukosit/ leucodepleted packed red cells (LD-PRC)}

American Academy of Blood Banks (AABB) mendefinisikan LD-PRC sebagai komponen darah PRC yang memiliki jumlah leukosit $<5 \times 10^{6}$ per unit kantong darah. Teknologi yang digunakan untuk menghasilkan leukodeplesi mencakup proses sentrifugasi dan pembekuan, filtrasi, dan apheresis. Istilah lain yang dapat digunakan untuk mendeskripsikan LD-PRC adalah leucoreduced PRC atau leuco-poor PRC. ${ }^{8}$ Palang Merah Indonesia (PMI) menggunakan pengertian yang sedikit berbeda, seperti tertera pada Tabel $1 .{ }^{9}$

Untuk mengurangi jumlah leukosit dalam produk darah, terdapat dua pilihan prosedur yakni pre-storage filter atau post-storage filter/bedside filter. Secara umum, pre-storage filter memiliki keuntungan yaitu mengurangi akumulasi dari metabolit yang timbul akibat degradasi dari leukosit serta mengurangi pengeluaran sitokin inflamasi yang berada di dalam leukosit, alloimunisasi HLA, dan trombositopenia refrakter sebelum sel darah merah lisis. Sedangkan, pada penggunaan bedside filter, reaksi transfusi dapat terjadi akibat pengeluaran sitokin dan interleukin dari sel darah merah yang pecah selama penyimpanan. ${ }^{9}, 10$

Indikasi mutlak penggunaan transfusi LD-PRC pada pasien neonatus transfusi rutin, seperti pada thalassemia mayor dan anemia aplastik, dan pre-/ pasca-transplantasi organ. ${ }^{9}$ Transfusi LD-PRC dapat menurunkan risiko penularan infeksi cytomegalovirus (CMV) dan mencegah febrile non-hemolytic transfusion reactions (FNHTR) pada pasien yang sebelumnya pernah mengalami reaksi berupa demam setelah transfusi dua kali atau lebih sebelumnya. Dosis 
pemberian transfusi LD-PRC sama dengan dosis transfusi PRC secara umum.

\section{Sel darah merah teriradiasi/irradiated packed red cells (I-PRC)}

Pembuatan produk I-PRC dilakukan dengan proses iradiasi gamma dari produk darah selular. Penggunaan I-PRC secara umum ditujukan untuk mencegah transfusion-associated graft-versus-host disease (TAGvHD), yaitu sel limfosit dari darah donor yang masuk ke dalam sistem sirkulasi resipien menimbulkan tanda dan gejala berupa demam, ruam kulit, diare, dan pansitopenia. Pasien immunocompromised seperti pasien pasca-transplantasi dan sebagainya, cenderung memiliki risiko lebih tinggi untuk mengalami TAGvHD. ${ }^{11}$

\section{Sel darah merah cuci/washed erythrocytes (WE)}

Indikasi dan rekomendasi pemberian transfusi WE serupa dengan PRC. Transfusi WE dapat diberikan pada pasien dengan riwayat reaksi alergi atau demam pada episode transfusi sebelumnya, hiperkalemi, defisiensi IgA, atau memiliki alergi terhadap protein plasma. Dosis WE pada anak untuk transfusi masif adalah 10-15 mL/kgBB, bergantung pada keadaan umum saat pemeriksaan. Pada pasien anak secara umum, pemberian WE $8 \mathrm{~mL} / \mathrm{kg}$ dapat meningkatkan kadar $\mathrm{Hb}$ sekitar $1 \mathrm{~g} / \mathrm{dL} .{ }^{1}$

Perbedaan WE dan LD-PRC berdasarkan definisi yang dianut oleh PMI adalah dari jumlah leukosit yang ada per unit kantong darah, WE mengandung $10^{7}$ leukosit per unit kantong darah, sedangkan LDPRC mengandung $<10^{6}$ per unit kantong darah. ${ }^{9}$ Keuntungan penggunaan WE adalah komponen plasma/supernatant berkurang yang umumnya merupakan salah satu penyebab reaksi transfusi. Kerugian penggunaannya membutuhkan tenaga kerja yang intensif dan waktu yang lama sehingga tertunda. Selain itu, produk WE juga kadaluwarsa dalam 24 jam setelah pembuatan. ${ }^{1}$

\section{Transfusi trombosit konsentrat/thrombocyte concentrate (TC)}

Transfusi TC dapat diberikan pada pasien yang mengalami perdarahan akibat trombositopenia, atau sebagai profilaksis pada keadaan tertentu. Pada pasien dengan trombositopenia, transfusi TC profilaksis dapat diberikan pada kadar trombosit $<50.000 / \mu \mathrm{L}$, namun sebagian institusi menggunakan kesepakatan untuk memberikan pada kadar trombosit $<20.000 / \mu \mathrm{L}$. Namun, hal ini juga harus mempertimbangkan kondisi klinis pasien. Pasien yang dijadwalkan untuk prosedur invasif juga dapat diberikan transfusi TC profilaksis apabila kadar trombosit $<50.000 / \mu \mathrm{L}$.

Pada pasien dengan trombositopenia dengan perdarahan aktif, pemberian transfusi TC dibenarkan pada kadar trombosit berapapun. Transfusi TC juga dapat diberikan pada pasien dengan perdarahan aktif yang memiliki defek trombosit kualitatif (trombopati). Selain itu, pada pasien anak dengan kadar trombosit $<20,000 / \mu \mathrm{L}$ yang akan menjalani tindakan prosedur invasif sebaiknya diberikan transfusi trombosit sebagai profilaksis walaupun tanpa perdarahan aktif. Satu kantong TC dianggap dapat meningkatkan kadar trombosit $5.000-10,000 / \mathrm{mL}$. Dosis pemberian TC pada anak dan neonatus adalah $10-20 \mathrm{~mL} / \mathrm{kgBB} /$ hari. ${ }^{1,7}$

Apheresis adalah prosedur yang digunakan untuk memisahkan komponen yang diinginkan dari komponen lainnya pada produk darah donor. Apheresis dapat digunakan untuk beberapa komponen darah tertentu, salah satunya adalah trombosit. Apheresis yang dilakukan untuk mendapatkan trombosit dari darah donor disebut plateletpheresis/thrombopheresis. Adapun keuntungan dari penggunaan produk apheresis adalah produk darah yang digunakan berasal dari satu donor, sehingga kemungkinan terjadi reaksi transfusi dan penularan infeksi dapat dicegah. ${ }^{12}$ Bentuk lain dari sediaan komponen trombosit yang tersedia di PMI adalah pooled unit TC, yang merupakan produk TC yang berasal dari 4-6 orang donor, yang kemudian dimasukkan ke dalam satu kantong. Setelah pooled unit TC disiapkan, harus segera ditransfusikan, karena adanya risiko proliferasi bakteri. ${ }^{1}$

\section{Transfusi granulosit/buffy coat}

Buffy coat adalah suspensi leukosit konsentrat, yang mengandung komponen sel darah putih dan trombosit dari suatu sampel darah. ${ }^{13}$ Indikasi transfusi granulosit pada pasien dengan neutropenia, leukemia, penyakit keganasan lain, serta anemia aplastik dengan jumlah hitung leukosit $<2.000 / \mathrm{mm}^{3}$ dengan suhu $>39,0^{\circ} \mathrm{C}$. Jumlah pemberian transfusi granulosit pada umumnya 
$1-2 \times 10^{\%} / \mathrm{kgBB}$ setiap transfusi untuk neonatus, $1-2 \times 10^{10} / \mathrm{kgBB}$ untuk bayi dan anak yang lebih besar, dan $2-3 \times 10^{10} / \mathrm{kgBB}$ untuk remaja. Satu unit granulosit mengandung $1 \times 10^{10}$ granulosit. Namun, saat ini transfusi granulosit sudah jarang digunakan. ${ }^{14}$

\section{Plasma segar beku/fresh frozen plasma (FFP)}

Tujuan dari transfusi FFP untuk mengganti defisiensi faktor koagulasi, terutama faktor IX pada pasien dengan hemofilia B dan faktor inhibitor koagulasi, baik yang didapat atau bawaan apabila tidak tersedia komponen konsentrat dari faktor spesifik atau faktor kombinasi. Dosis pemberian transfusi FFP pada anak dan neonatus $10-20 \mathrm{~mL} / \mathrm{kgBB} /$ hari. ${ }^{1}$ Pemberian transfusi FFP dapat bermanfaat pada populasi anak yang mengalami disseminated intravascular coagulation (DIC) dengan koagulopati yang signifikan (PT/ APTT $>1,5$ titik tengah dari rentang nilai normal atau fibrinogen $<0,1 \mathrm{~g} / \mathrm{dL}$ ) yang dikaitkan dengan perdarahan yang signifikan secara klinis atau sebelum prosedur invasif. ${ }^{14}$

\section{Kriopresipitat}

Tujuan dari transfusi kriopresipitat untuk mengganti defisiensi faktor VIII pada pasien hemofilia A, penyakit von Willebrand yang mengalami perdarahan atau tidak menunjukkan respon terhadap pemberian desmopresin asetat, serta akan menjalani operasi/tindakan invasif. Kriopresipitat juga dapat digunakan sebagai profrilaksis pada pasien dengan defisiensi fibrinogen yang akan menjalani prosedur invasif dan terapi pada pasien yang mengalami perdarahan. ${ }^{1}$

Sebagai pengganti fibrinogen, penggunaan satu unit kriopresipitat per $5 \mathrm{~kg}$ berat badan secara umum dapat meningkatkan konsentrasi fibrinogen $100 \mathrm{mg} /$ dL, kecuali pada kasus DIC atau perdarahan masif. Transfusi yang dilaksanakan harus berdasarkan pada kondisi klinis, dengan tujuan mencapai dan mempertahankan konsentrasi fibrinogen pada 100 $\mathrm{mg} / \mathrm{dL}$, sebagaimana diindikasikan secara klinis. Secara umum, penghitungan jumlah kantong dapat menggunakan rumus $0,2 \mathrm{x}$ berat badan dalam $\mathrm{kg}$ untuk meningkatkan konsentrasi fibrinogen $100 \mathrm{mg} /$ dL. Dalam praktiknya, dapat diberikan 10-20 unit/ $\mathrm{kgBB} / 12$ jam, karena waktu paruh kriopresipitat 12 jam. Satu kantong kriopresipitat berisi sekitar 30-40 $\mathrm{mL}$, dan mengandung faktor VIII 70-75 unit. ${ }^{15,16}$

\section{Pemantauan pelaksanaan transfusi}

Pemantauan pelaksanaan transfusi idealnya dilakukan sebelum dimulai transfusi, 15 menit pertama setelah dimulai transfusi, setiap jam setelah dimulai transfusi, saat selesai transfusi, dan 4 jam setelah selesai tranfsusi untuk pasien rawat inap. Namun, hal ini tentu bergantung dari sarana dan prasarana yang tersedia, sehingga setiap institusi disarankan untuk memiliki pedoman pelaksanaan transfusi. Pemantauan pelaksanaan transfusi, mencakup keadaan umum pasien, suhu tubuh, frekuensi nadi, tekanan darah, frekuensi nafas, serta keluhan yang dirasakan oleh pasien. Pemberian diuretik tidak dilakukan secara rutin, dan hanya pada kasus yang diduga akan atau sudah terdapat tanda dekompensasi jantung. ${ }^{1}$

\section{Reaksi transfusi}

Berdasarkan tipe, reaksi transfusi dapat dibagi menjadi dua kategori,

- Reaksi transfusi imunologis, dibagi menjadi reaksi cepat, yang mencakup reaksi hemolitik akut, destruksi trombosit, demam non-hemolitik, reaksi alergi, reaksi anafilaktik, serta transfusion-related acute lung injury (TRALI). Reaksi lambat yang mencakup reaksi hemolitik lambat, aloantibodi, purpura pasca-transfusi transfusion-associated graft versus host disease (TAGvHD).

- Reaksi transfusi non-imunologis, mencakup infeksi yang ditularkan melalui darah, sepsis, transfusion-associated circulatory overload (TACO), dan gangguan metabolik. ${ }^{9}$

Berdasarkan keluhan dan tanda, reaksi transfusi dapat dikelompokkan menjadi 3 kategori,

- Kategori I (reaksi ringan), berupa demam dengan suhu $>38,0^{\circ} \mathrm{C}$ atau kenaikan suhu $1-2^{\circ} \mathrm{C}$ dari suhu tubuh pra-transfusi, pruritus, ruam ringan, transient urticaria, atau flushing.

- Kategori II (reaksi sedang), di samping demam dengan suhu tubuh $>39,0^{\circ} \mathrm{C}$ atau kenaikan suhu $>2^{\circ} \mathrm{C}$ dari suhu tubuh pra-transfusi, disertai menggigil, rasa kaku, mual/muntah, mialgia, angioedema, mengi, urtikaria, serta ruam kulit, tanpa gangguan pada sirkulasi dan pernapasan.

- Kategori III (reaksi berat), terjadi hipotensi atau 
gangguan sirkulasi, sesak napas, mengi, stridor berat, serta anafilaksis. ${ }^{1}$

Pemberian profilaksis untuk mencegah reaksi transfusi dapat diberikan pada kasus yang pernah mengalami riwayat reaksi transfusi sebelumnya, terutama saat pemberian produk darah yang mengandung plasma. Namun, penggunaan profilaksis umumnya tidak dilakukan di negara yang sudah menggunakan pre-storage filter untuk setiap produk darahnya. ${ }^{1}$

\section{Kesimpulan}

- Transfusi darah adalah prosedur yang ditujukan untuk menambah atau menggantikan komponen darah yang tidak mencukupi untuk mencegah terjadinya dampak dari kurangnya komponen darah tersebut. Pelaksanaan transfusi secara rasional mencakup pemberian komponen darah tertentu sesuai kebutuhan dan berdasarkan pedoman yang berlaku.

- Perbedaan pelaksanaan transfusi pada anak dan dewasa adalah pada berat badan dan usia anak yang digunakan untuk menghitung jumlah komponen darah yang dibutuhkan, serta kapasitas kardiopulmonal pada anak sesuai tahapan pertumbuhannya.

- Pemberian transfusi darah atau komponen darah harus mempertimbangkan risiko dan keuntungannya, serta harus rasional dan adekuat. Kontraindikasi transfusi darah apabila tidak ada indikasi.

- Transportasi komponen darah dilakukan menggunakan cool box khusus dengan termometer untuk memantau suhu ideal, misalkan $2-6^{\circ} \mathrm{C}$ untuk sel darah merah, $14-22^{\circ} \mathrm{C}$ untuk komponen plasma, dan sebagainya. Urutan cara meletakkan es beku yang dilapisi oleh alas di atasnya, lalu diletakkan komponen darah yang akan dibawa.

- Tidak diperkenankan untuk memasukkan komponen lain ke dalam kantong darah.

- Ideal jika setiap pemberian komponen darah menggunakan set transfusi yang berbeda.

- Pada pemberian transfusi darah, darah/komponen tidak perlu dihangatkan terlebih dahulu kecuali pada transfusi cepat, transfusi masif, transfusi tukar, atau terdapatnya cold agglutinin.
- Jika memungkinkan, dianjurkan untuk memakai produk darah rendah leukosit, terutama untuk pasien neonatus, transfusi rutin/berulang, transplantasi, dengan skrining nucleic acid amplification testing (NAT).

- Pelaksanaan transfusi darah sebaiknya dimulai maksimal 30 menit setelah produk darah tersebut dikeluarkan oleh Unit Pelayanan Transfusi Darah (UPTD) / bank darah.

- Pemberian transfusi darah pekat/sel darah merah kepada resipien harus selesai dalam waktu maksimal $4 \mathrm{jam} /$ kantong terhitung dari keluarnya produk darah dari UPTD, sedangkan untuk produk plasma darah dapat diberikan lebih cepat (dalam 1-2 jam), bergantung kebutuhan.

- Jarak pemberian antara dua kantong PRC sebaiknya 24 jam. Namun, pada penyakit kronik dengan kadar $\mathrm{Hb}<5 \mathrm{~g} / \mathrm{dL}$, jarak minimal yang masih diperkenankan adalah antara 8-12 jam setelah kantong darah pertama selesai.

- Pemberian diuretik tidak dilakukan secara rutin dan hanya diberikan pada keadaan khusus, seperti gagal jantung.

- Penggunaan $\mathrm{NaCl}$ 0,9\% tidak diberikan untuk pembilasan setelah transfusi selesai, untuk menghindari kelebihan cairan.

- Apabila pada satu pasien dibutuhkan lebih dari satu jenis komponen darah, komponen darah dapat diberikan secara berurutan, tetapi tidak melebihi jumlah kebutuhan cairan pasien dalam 24 jam. Urutan pemberian komponen juga disesuaikan dengan kondisi klinis. Sebagai contoh, pada kasus perdarahan akibat trombositopenia, disarankan untuk diberikan komponen TC terlebih dahulu kemudian dilanjutkan komponen PRC.

\section{Daftar pustaka}

1. RSUPN Dr. Cipto Mangunkusumo. Panduan pelayanan transfusi darah. Jakarta; 2015.

2. WHO. The clinical use of blood in general medicine, obstetrics, paediatrics, surgery $\&$ anaesthesia, trauma $\&$ burns. World Health Organization. Geneva; 2016.

3. Guidelines for the blood transfusion services in the United Kingdom. Joint United Kingdom (UK) Blood Transfusion and Tissue Transplantation Services Professional Advisory Committee. London; 2013. 
4. Clarke G, Charge S. Clinical guide to transfusion medicine. Canadian Blood Services; 2013.

5. Pediatric transfusion guidelines. University of California Davis; 2006.

6. Hume HA, Limoges P. Perioperative blood transfusion therapy in pediatric patients. American J Ther 2002; 9:396-405.

7. Roseff SD, Luban NL, Manno CF. Guidelines for assessing appropriateness of pediatric transfusion. Transfusion 2002; 42:1398-413.

8. Chapman JF, Forman K, Kelsey P, Wood JK. Guidelines on the clinical use of leucocyte-depleted blood components. Transfus Med 1998; 8:59-71.

9. Wahidiyat PA, Rahmartani LD, Putriasih SA. Pemakaian klinis produk darah pada kasus transfusi berulang. Divisi Hematologi-Onkologi, Departement Ilmu Kesehatan Anak, RSUPN Dr. Cipto Mangunkusumo; 2016.

10. Brownlee L, Wardrop KJ, Sellon RK, Meyers KM. Use of a prestorage leukoreduction filter effectively removes leukocytes from canine whole blood while preserving red cell viability. J Vet Intern Med 2000; 14:412-7.

11. Olivo RA, Silva MVD, Garcia FB, Moraes-Souza H. Evalua- tion of the effectiveness of packed red blood cell irradiation by a linear accelerator. Rev Bras Hematol Hemoter 2015;37:153-9.

12. Mallhi RS, Kumar S, Philip J. A comparative assessment of quality of platelet concentrates prepared by buffy coat poor platelet concentrate method and apheresis derived platelet concentrate method. Indian J Hematol Blood Transfus 2015; 31:453.

13. Rhenen DV, Gulliksson H, Cazenave JP, Corash L, dkk. Transfusion of buffy coat components prepared with photochemical pathogen inactivation treatment: the euroSPRITE trial. Blood 2003;101:2426-33.

14. Strauss RG. Transfusion of blood and blood components. Dalam: Kliegman RM, Stanton BF, St. Geme JW, Schor NF, Behrman RE, penyunting. Nelson textbook of pediatrics. Edisi ke-19. Philadelphia: WB Saunders; 2011. h.1727-32.

15. New HV, Berryman J, Bolton-Maggs PHB, Stanworth SJ. Guidelines on transfusion for fetuses, neonates and older children. British Committee for Standards in Hematology; 2014.

16. Callum JL, Karkouti K, Lin Y. Cryoprecipitate: The current state of knowledge. Transfus Med Rev 2009; 23:177-88. 